\title{
Accounting
}

\section{Determinants of the Islamic financial literacy}

\author{
Gatot Nazir Ahmad ${ }^{\mathrm{a}}$, Umi Widyastuti ${ }^{\mathrm{a}^{*}}$, Santi Susanti ${ }^{\mathrm{a}}$ and Hasan Mukhibad ${ }^{\mathrm{b}}$
}

${ }^{a}$ Faculty of Economics, Universitas Negeri Jakarta, Indonesia

${ }^{b}$ Faculty of Economics, Universitas Negeri Semarang, Indonesia

\section{H R O N I C L E}

\section{Article history:}

Received March 182020

Received in revised format May

262020

Accepted July 292020

Available online

July 292020

Keywords:

Islamic financial literacy

Subjective knowledge

Sharia compliance

Riba

Profit-sharing

\section{A B S T R A C T}

Financial literacy is one of the human capitals, which has a contribution in influencing financial behavior. In line with the development of Islamic financial products, the Islamic financial literacy is needed to be enhanced to support people's financial decision making. This study aims to determine the dimensions of Islamic financial literacy. The study used 472 Sharia mutual funds' individual investors who were collected using convenience sampling technique. Islamic financial literacy in this study was measured using 9 indicators. Based on exploratory factor analysis (EFA), two dimensions of Islamic financial literacy were extracted: the first dimension is labelled subjective knowledge of Sharia compliance and the second dimension is named subjective knowledge of riba and profitsharing.

\section{Introduction}

(C) 2020 by the authors; licensee Growing Science, Canada

The importance of financial literacy has been empirically proven to influence individual's financial behavior. By exploring many types of financial behavior, Lusardi and Mitchell (2007), Huston (2010), Widyastuti, Sumiati, Herlitah, and Melati (2020), have shown that financial literacy may lead people in making various key financial behavior or financial decisions. Financial literacy is one of the human capitals, which could promote desirable individual's financial behavior, such as financial planning (Zulaihati, Susanti, \& Widyastuti, 2020), saving (Jamal, Ramlan, Karim, \& Osman, 2015; Lusardi, 2008; Zulaihati et al., 2020), retirement saving decisions (Clark, Lusardi, \& Mitchell, 2016), and investment behavior (Sivaramakrishnan, Srivastava, \& Rastogi, 2017). In the context of Islamic financial products, we assume that Islamic financial literacy is also needed to support people in making financial decision.

The Islamic finance has expanded for the last two decades (Jaballah, Peillex, \& Weill, 2018), therefore Islamic financial products have been increasing, including in banking and financial industry. Islamic financial products have been offered not only for Moslem, but also non-Moslem consumers (Chong \& Liu, 2009). Therefore, people's understanding about the concept of Islamic finance should be enhanced. It is shown by the low level of Islamic financial index. As reported by Financial Service Authority

* Corresponding author.

E-mail address: umiwidyastuti_feunj@unj.ac.id (U. Widyastuti) 
(Otoritas Jasa Keuangan), the evidence from Indonesia has shown that the level of Islamic financial literacy index is only 9.10 percent (OJK, 2020).

Due to the development of financial products based on Islamic principal, the concept of Islamic financial literacy emerges as an interesting topic to be explored. Some prior researches evolved the definition of Islamic financial literacy by referring to the concept of financial literacy (Antara, Musa, \& Hassan, 2016). Nevertheless, along with the development of the Islamic financial industry, there is a lack of studies which define and measure Islamic financial literacy. Therefore, this study will contribute in developing the concept of Islamic financial literacy by determining the dimensions that indicate Islamic financial literacy.

\section{Literature Review}

The concept of financial literacy is often associated with various terms including financial knowledge, financial capability, financial education, and financial competence. Zait and Bertea (2015) explained that these terms were interchangeable. Conversely, some studies stated that each concept has a different meaning. According to Huston (2010), financial education is defined as a process which is intended for enhancing one's human capital, especially financial knowledge and its application. While financial competence explains about individual's knowledge and behavior that contribute to their financial capabilities. Each concept is interrelated, but it could not be interchanged with each other. Financial literacy is dominantly defined as financial knowledge (Hogarth \& Hilgert, 2002; Hung, Parker, \& Yoong, 2009; Lusardi \& Mitchell, 2005). Financial knowledge is the most obvious conceptual definition of financial literacy, but Huston (2010) highlighted two dimensions which reflects financial literacy, including knowledge and application dimensions. Moreover, Huston (2010) stated that knowledge dimension focused on the knowledge that acquired from education related to the personal finance concept, while application dimension emphasized on person's ability and confidence to apply their financial knowledge in making financial decisions. In accordance with the reference above, Remund (2010) conceptualized financial literacy which were categorized into five dimensions namely (1) knowledge about financial concepts (2) ability to communicate about financial concepts, (3) aptitude in managing personal finances, (4) skill in making appropriate financial decisions and (5) confidence in planning effectively for future financial needs.

Besides the definition of financial literacy, Huston (2010) stated that there are no standardized instruments for measuring financial literacy. Fernandes, Lynch Jr, and Netemeyer (2014) expressed that the measurement of financial literacy emphasized on objective knowledge. Using true or false questions, Hogarth and Hilgert (2002) examined knowledge about credit, saving patterns, mortgages, and general financial management. On the other hand, Lusardi and Mitchell (2005) examined the level of financial literacy through the question about compound interest, inflation, and risk diversification. Subsequently, Lusardi and Mitchell (2007) operationalized financial literacy which consist of basic and sophisticated elements. Lusardi and Mitchell (2007) modified the instrument that used in previous study by adding some indicators (i.e. time value of money and money illution) which reflects basic financial literacy.

Based on the literature review about financial literacy, we can summarize that financial literacy could be conceptualized based on a different dimension and could be measured using different instrument. By referring to the concept of financial literacy, some researchers developed the concept of Islamic financial literacy and discussed about the dimensions which is used to measure it. According to Antara et al. (2016), Islamic financial literacy has measured using a true or false questionnaire which reflects two dimensions namely: Islamic finance principal and Islamic finance methods, while Hidajat and Hamdani (2017) specifically built some true or false question which reflects riba, salam, murabahah, istishna', ijarah, mudharabah, and musyarakah. This study elaborate these references to develop the concept of Islamic financial literacy.

\section{Research Methodology}

The purpose of this study is to determine the dimensions of Islamic financial literacy, therefore this study applied a quantitative approach using EFA (Hair, Black, Babin, \& Anderson, 2010). EFA is the tools that enable to analyze high interrelationships among the set of variables which known as factors or components or dimensions.

The primary data were collected from 472 individual investors of Sharia mutual funds. Islamic financial literacy was measured by online instrument using five points of Likert's scale that started from 1 (strongly disagree) until 5 (strongly agree). The sample were obtained by applying convenience sampling technique.

The procedures in EFA is started by the test of adequacy of sample size. One measure of how well a variable is accounted for in the retained factors is communality - the amount of a variable's variance explained by its loadings on the factors (Hair Jr., Black, Babin, \& Anderson, 2019). Fabrigar and Wegener (2012) stated that if the communalities are below .40 and there are few high loadings per factor, sample sizes of up to 400 are appropriate.

Refer to Hair Jr. et al. (2019), to assess the data sufficiency in factor analysis, this two criterion can be applied including: Kaiser Meyer Olkin - Measure of Sampling Adequacy (KMO - MSA) and Bartlett's Test of Sphericity. The first criterion is KMO- 
MSA that should be between 0 to 1 . If the KMO-MSA exceed than 0.5 , it could be said that the data is suitable for factor analysis. The second criterion is Bartlett's Test of Sphericity. The Bartlett's test of sphericity should be significant $(\mathrm{p}<0.05)$, therefore this could be concluded that the factor analysis is suitable. If the requirement of sample size has been fulfilled, the next step is reduction of the large number of variables into the dimensions using the principal component analysis (PCA), as one of the extraction methods. Some approaches can be used to determine the factor extraction, including the Eigenvalue, cumulative percent of variance extracted, and scree plot test (Williams, Onsman, \& Brown, 2010), This study used all of the criterion for the procedure of factor extraction. Factor will be formed when the Eigenvalue is more than 1, while the cumulative percent of variance results from the eigenvalue. If the eigenvalues are added, the result should be the total variance in the correlation matrix. The percentage of explained variance of each component can be easily computed as the corresponding eigenvalue divided by the total variance. Hinkin (1998) argues that 60 percent should be a minimum value of the percentage of explained variance, but according to Hair Jr. et al. (2019), in the social sciences, where information is often less precise, it is not uncommon to consider a solution that accounts for 60 percent of the total variance as satisfactory, and in some instances even less. Another criterion in determining the factor extraction is rotation method. This study applies the varimax rotation to represent the factor that uncorrelated. After the rotation step, the final procedure is give the label for the factor extracted by referring to the theory or relevant research.

\section{Results and Discussion}

An EFA is the analysis which is used to extract the large number of variable into dimensions. Table 1 displays the values of anti image correlation for each item that measures Islamic financial literacy.

\section{Table 1}

Anti Image Correlation

\begin{tabular}{|c|c|c|c|c|c|}
\hline Items & Anti Image Correlation & Items & Anti Image Correlation & Items & Anti Image Correlation \\
\hline IFL 1 & .800 & IFL4 & .650 & IFL8 & .729 \\
\hline IFL2 & .635 & IFL5 & .794 & IFL9 & .780 \\
\hline IFL3 & .801 & IFL7 & .739 & IFL11 & .720 \\
\hline
\end{tabular}

Based on the anti image correlation, we know that all of the items were valid, since the value of anti image correlation exceeds 0.5. Therefore, the EFA analysis could be proceed into the next step. After the validity test, the next step in EFA is the test of adequacy sample size based on KMO-MSA and Bartlett's test of sphericity. As represented in Table 2, this study has the KMOMSA 0.749, while the Barlett's test of sphericity is significant on 5 percent level of significant. Based on both criterion, it means that this study has sufficient sample size to be analyized using EFA. Therefore, the step could be proceed further.

\section{Table 2}

KMO and Bartlett's Test

Kaiser-Meyer-Olkin Measure of Sampling Adequacy.

Bartlett's Test of Sphericity

In this study, the factor extraction is conducted by applying PCA. The scree plot represented on Fig. 1 that represent the number of factors which extracted based on Eigenvalue $>1$. This figure is reinforced by the result of factor extraction based on Eigenvalue that represent in Table 3. Based on Table 3, two factors have been extracted from this analysis. Each factor has the Eigenvalue as follows: 2.947 for the first factor and 1.251 for the second factor.

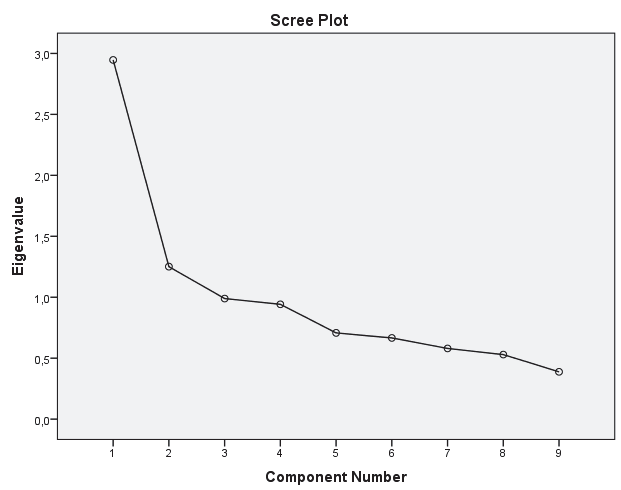

Fig. 1. Scree Plot 
Another criterion in factor extraction is total cumulative variance. According to Hair Jr. et al. (2019), it is enable to have the total cumulative variance less than sixty percent for the construct in social science. The two factors retained represent 46.6 percent of the variance from the 9 indicators. After the rotation method using varimax, the two factors that have been extracted will be labelled by referring to the previous research.

Table 3

The total cumulative variance

\begin{tabular}{|c|c|c|c|c|c|c|}
\hline \multirow[b]{2}{*}{ Component } & \multicolumn{3}{|c|}{ Initial Eigenvalues } & \multicolumn{3}{|c|}{ Extraction Sums of Squared Loadings } \\
\hline & Total & $\%$ of Variance & Cumulative $\%$ & Total & $\%$ of Variance & Cumulative $\%$ \\
\hline 1 & 2.947 & 32.740 & 32.740 & 2.947 & 32.740 & 32.740 \\
\hline 2 & 1.251 & 13.899 & 46.639 & 1.251 & 13.899 & 46.639 \\
\hline 3 & .989 & 10.992 & 57.631 & & & \\
\hline 4 & .942 & 10.468 & 68.099 & & & \\
\hline 5 & .708 & 7.861 & 75.960 & & & \\
\hline 6 & .666 & 7.401 & 83.361 & & & \\
\hline 7 & .580 & 6.444 & 89.805 & & & \\
\hline 8 & .530 & 5.883 & 95.688 & & & \\
\hline 9 & .388 & 4.312 & 100.000 & & & \\
\hline
\end{tabular}

The rotation method using varimax is conducted to determine the loading factor for each item and to categorize the items which build the factors. Hinkin (1998) stated that the loading factor should exceed than 0.4. The first component or factor consists of five items namely: item numbers 7, 3, 9, 5, and 1 . The second component or factor consists of four items, including item numbers $2,4,8,10$. The details of loading factors for each item are represented in Table 4, while the details of items in each dimension are displayed in Table 5.

Table 4

Rotated Component Matrix

\begin{tabular}{lll}
\hline & \multicolumn{1}{c}{ Component } \\
\cline { 2 - 3 } & \multicolumn{1}{c}{2} \\
\hline IFL7 & .749 \\
IFL3 & .690 \\
IFL9 & .671 \\
IFL5 & .606 \\
IFL1 & .556 & \\
IFL2 & & \\
IFL4 & & .685 \\
IFL8 & & .619 \\
IFL10 & .445 & .594 \\
\hline
\end{tabular}

After the rotation method using varimax, the two factors that have been extracted will be labelled by referring to the previous research. According to Hidajat and Hamdani (2017), Islamic financial literacy is measured as knowledge about Islamic finance in making financial decisions, while Antara et al. (2016) developed the instrument of Islamic financial literacy which reflects the Islamic finance principal and method.

Table 5

Labelling Dimension

\begin{tabular}{|c|c|c|c|c|}
\hline No & $\begin{array}{c}\text { Name of } \\
\text { dimension }\end{array}$ & $\begin{array}{c}\text { Items } \\
\text { number }\end{array}$ & Items & $\begin{array}{l}\text { Factor } \\
\text { loading }\end{array}$ \\
\hline \multirow[t]{5}{*}{1} & \multirow{5}{*}{$\begin{array}{l}\text { Subjective } \\
\text { knowledge of } \\
\text { Sharia compliance }\end{array}$} & IFL7 & $\begin{array}{l}\text { In mudharaba contract, a capital owner will bear all loses personally (except if the loses } \\
\text { are caused by negligence or moral hazard of his partner) }\end{array}$ & 0.763 \\
\hline & & IFL3 & $\begin{array}{l}\text { Profit taking in personal loan relationship activity is riba and it is } \\
\text { forbidden. }\end{array}$ & 0.727 \\
\hline & & IFL9 & $\begin{array}{l}\text { In musyaraka contract, the capital given must be cash money, gold, silver, or the other } \\
\text { valuable goods with same value. If the capital given is the asset with the form of goods, } \\
\text { then it must be assessed as cash money and it must be approved by the partner. }\end{array}$ & 0.672 \\
\hline & & IFL5 & Gharar refers to uncertainty and deception and not allowable in Islamic finance. & 0.598 \\
\hline & & IFL1 & Islamic method of finance is interest-free. & 0.553 \\
\hline \multirow[t]{4}{*}{2} & \multirow{4}{*}{$\begin{array}{l}\text { Subjective } \\
\text { knowledge of riba } \\
\text { and profit-sharing. }\end{array}$} & IFL2 & Riba (usury) is haram and it is forbidden. & 0.699 \\
\hline & & IFL4 & Exchange process of similar goods with different dose or level is riba. & 0.625 \\
\hline & & IFL8 & $\begin{array}{l}\text { In mudharaba contract, if the business managed by mudharib gets profit, then the partner } \\
\text { and capital owner will share the profit based on proportion approved before. }\end{array}$ & 0.544 \\
\hline & & IFL10 & In musyaraka contract, the profit gained must be shared proportionally. & 0.452 \\
\hline
\end{tabular}

In this study, the Islamic financial literacy measures investor's perception about their knowledge of Islamic concept. Hadar, Sood, and Fox (2013) used the term of subjective knowledge to measure the consumers' assessment of their knowledge. 
Therefore, the first factor is labelled as subjective knowledge of Sharia compliance. This factor presents the knowledge about some guidance in conducting economic activity (muamalah) based on Islamic principles. This label is supported by Abdullah and Razak (2015) who defines Islamic financial literacy as the ability to understand finance based on sharia compliance.

The second factor is labelled as the subjective knowledge of riba and profit-sharing. It measures people's understanding of concept of riba and profit-sharing. Refers to some previous researches, the items of Islamic financial literacy focused on the interest-free system (Antara et al., 2016; Hidajat \& Hamdani, 2017) known as riba, and profit-sharing in the economic activities such as in musyaraka, mudharabah contracts (Hidajat \& Hamdani, 2017). Based on the data analysis, the findings show that the dimensions of Islamic financial literacy in this study are categorized in two factors, including subjective knowledge of Sharia compliance and subjective knowledge of riba and profit-sharing concept.

\section{Conclusion}

This study has aimed to identify potential underliying dimensions of Islamic financial literacy. Based on factor analysis, two factors of Islamic financial literacy have been extracted, and these factors were labelled as follows: Subjective knowledge of Sharia compliance and knowledge of riba and profit-sharing concept. This study is limited in measuring Islamic financial literacy based on the perception of investors of Sharia mutual funds. The measurement could be extended by elaborating previous studies and applied in another sample.

\section{Acknowledgment}

The authors would like to thank the anonymous reviewers and editors for their excellent comments, which resulted in a significant improvement in the quality of this paper.

\section{References}

Abdullah, R., \& Razak, A. (2015). Exploratory research into Islamic financial literacy in Brunei Darussalam (pp. 61-87).

Antara, P. M., Musa, R., \& Hassan, F. (2016). Bridging Islamic financial literacy and halal literacy: the way forward in halal ecosystem. Procedia Economics and Finance, 37, 196-202.

Chong, B. S., \& Liu, M.-H. (2009). Islamic banking: interest-free or interest-based? Pacific-Basin Finance Journal, 17(1), 125144.

Clark, R., Lusardi, A., \& Mitchell, O. S. (2016). Employee financial literacy and retirement plan behavior: a case study. Economic Inquiry, 55(1), 248-259.

Fabrigar, L., \& Wegener, D. (2012). Exploratory Factor Analysis: New York, USA: Oxford University Press.

Fernandes, D., Lynch Jr, J. G., \& Netemeyer, R. G. (2014). Financial literacy, financial education, and downstream financial behaviors. Management Science, 60(8), 1861-1883.

Hadar, L., Sood, S., \& Fox, C. R. (2013). Subjective knowledge in consumer financial decisions. Journal of Marketing Research, $50(3), 303-316$.

Hair, J. F., Black, W. C., Babin, B. J., \& Anderson, R. E. (2010). Multivariate data analysis (7th ed.): Pearson. New Jersey.

Hair Jr., J. F., Black, W. C., Babin, B. J., \& Anderson, R. E. (2019). Multivariate data analysis: Cengage.

Hidajat, T., \& Hamdani, M. (2017). Measuring Islamic financial literacy. Advanced Science Letters, 23(8), 7173-7176.

Hinkin, T. R. (1998). A brief tutorial on the development of measures for use in survey questionnaires. Organizational Research methods, 1(1), 104-121.

Hogarth, J. M., \& Hilgert, M. A. (2002). Financial knowledge, experience and learning preferences: Preliminary results from a new survey on financial literacy. Consumer Interest Annual, 48(1), 1-7.

Hung, A. A., Parker, A. M., \& Yoong, J. (2009). Defining and measuring financial literacy. RAND Labor and Population Working Paper Series, WR-708. Retrieved from https://papers.ssrn.com/sol3/papers.cfm?abstract id=1498674

Huston, S. J. (2010). Measuring financial literacy. Journal of Consumer Affairs, 44(2), 296-316.

Jaballah, J., Peillex, J., \& Weill, L. (2018). Is Being Sharia compliant worth it? Economic Modelling, 72, 353-362.

Jamal, A. A. A., Ramlan, W. K., Karim, M. A., \& Osman, Z. (2015). The effects of social influence and financial literacy on savings behavior: A study on students of higher learning institutions in Kota Kinabalu, Sabah. International Journal of Business and Social Science, 6(11), 110-119.

Lusardi, A. (2008). Household saving behavior: The role of financial literacy, information, and financial education programs (No. w13824). National Bureau of Economic Research.

Lusardi, A., \& Mitchell, O. S. (2005). Financial literacy and planning: Implications for retirement wellbeing (108). Retrieved from http://www.mrrc.isr.umich.edu/

Lusardi, A., \& Mitchell, O. S. (2007). Financial literacy and retirement planning: New evidence from the Rand American Life Panel.

OJK. (2020). Hasil Survei Nasional Literasi Keuangan OJK 2013, 2016, dan 2019. Jakarta: Otoritas Jasa Keuangan. 
Remund, D. L. (2010). Financial literacy explicated: The case for a clearer definition in an increasingly complex economy. Journal of Consumer Affairs, 44(2), 276-295.

Sivaramakrishnan, S., Srivastava, M., \& Rastogi, A. (2017). Attitudinal factors, financial literacy, and stock market participation. International Journal of Bank Marketing, 35(5), 818-841.

Widyastuti, U., Sumiati, A., Herlitah, H., \& Melati, I. (2020). Financial education, financial literacy, and financial Behaviour: What does really matter? Management Science Letters, 10(12), 2715-2720.

Williams, B., Onsman, A., \& Brown, T. (2010). Exploratory factor analysis: A five-step guide for novices. Australasian Journal of Paramedicine, $8(3)$.

Zait, A., \& Bertea, P. E. (2015). Financial literacy-Conceptual definition and proposed approach for a measurement instrument. The Journal of Accounting and Management, 4(3), 37-42.

Zulaihati, S., Susanti, S., \& Widyastuti, U. (2020). Teachers' financial literacy: Does it impact on financial behaviour? Management Science Letters, 10(3), 653-658.

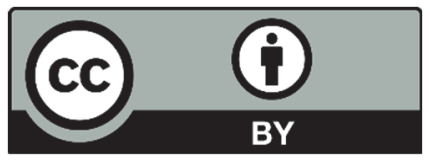

(C) 2020 by the authors; licensee Growing Science, Canada. This is an open access article distributed under the terms and conditions of the Creative Commons Attribution (CC-BY) license (http://creativecommons.org/licenses/by/4.0/). 